\title{
The Correlation between Serum C3 and C4 Complement Levels with Disease Activity of Systemic Lupus Erythematosus Patients in Dr. Soetomo Hospital, Surabaya
}

\author{
Istiana Hairiah Abas', Betty Agustina Tambunan², Awalia ${ }^{3}$ \\ ${ }^{1}$ Faculty of Medicine, Universitas Airlangga - Dr. Soetomo General Hospital Surabaya, Indonesia. \\ ${ }^{2}$ Department of Clinical Pathology, Faculty of Medicine, Universitas Airlangga \\ ${ }^{3}$ Department of Internal Medicine, Faculty of Medicine, Universitas Airlangga - Dr. Soetomo General Hospital Surabaya, \\ Indonesia.
}

\begin{abstract}
A B S T R A C T
Introduction: The Systemic lupus erythematosus (SLE) is an autoimmune disease that results in inflammation and tissue damage. SLE often creates difficulties in the diagnosis and assessment of disease activity. Disease activity is important as a basis for selecting the appropriate therapy. In addition to clinical SLE, supporting investigations are needed to determine disease activity, one of which is complement examination. Complement plays an important role in autoimmune disease and thought to mediate tissue damage. This study aimed to analyze the correlation between serum complement C3 and C4 levels with SLE patients' disease activity in Dr. Soetomo Hospital, Surabaya.

Methods: This study used an observational analytic method with a cross-sectional design. The sampling technique was consecutive sampling. The samples of this study were SLE patients who were treated in the inpatient room and poly rheumatology in January-December 2018 periods. The data were analyzed statistically using the Pearson test.

Results: There were 150 SLE patients, most of whom were women (90.0\%) with mean age of 29.01 \pm 9.8 years. Most levels of complement were low levels $(C 3=48.0 \%$ and $C 4=50.7 \%)$. Most disease activities were severe flares $(44.7 \%)$. Results of the Pearson test complement $\mathrm{C} 3$ with disease activity were $p=0.001$, and level of correlation was $r=-0.287$. However, results of the Pearson test complement $C 4$ with disease activity were $\mathrm{p}=0.026$, and level of correlation was $\mathrm{r}=-0.182$.

Conclusion: There is negative correlation between C3 and C4 complement levels with disease activity of SLE patients in Dr. Soetomo Hospital, Surabaya, which is significant, weak and opposite.
\end{abstract}

Keywords: Complement levels, Disease activity, Systemic lupus erythematosus

Correspondence: Betty Agustina Tambunan

E-mail: bettyagustina22@gmail.com

Article history: • Received 14 December $2020 \bullet$ Received in revised form 28 January $2021 \bullet$ Accepted 29 January 2021

\section{INTRODUCTION}

The systemic lupus erythematosus (SLE) is a systemic autoimmune disease that results in chronic inflammation, tissue damage, and diverse presentation of the disease course (Qu et al., 2018). The Lupus Foundation of America states that around 5 million people worldwide are affected by lupus, and there are 16,000 new cases reported each year (The Lupus Foundation of America, 2013). In 1998, there were only 586 lupus sufferers in Indonesia, and in 2005 there was an increase to 6,578 sufferers. Meanwhile, in April 2009, there were 8,891 lupus sufferers, and 15 died (Judha and Setiawan, 2015). Based on SIRS data for 2017 listed in the data and information center, there were 2,166 hospitalized patients diagnosed with lupus from the total of 858 hospitals that reported their data. Kementrian kesehatan reported an increase in cases of SLE. In 2016, it increased 2 times compared to 2014 (Kementrian Kesehatan, 2017).

SLE often creates difficulties in diagnosis and assessment of disease activity. Thus, investigations are needed to determine the prognosis of the disease. Investigations that can prove autoimmune in the patient, one of which is the serum complement immunology examination. Complement is compound in the blood involved in the immune system (Gandino et al., 2017). Complement exists in the circulation in an inactive state and can be activated via three routes: the classical route, the alternative route, and the lectin pathway. The dominant pathway for complement activation in SLE is the classic route. When there is the activation of SLE disease, complement levels can be measured by the radial immunodiffusion method (Hikmah and Prihaningtyas, 2018).

SLE can affect any tissue with mild to severe levels of symptoms. Assessment of disease activity is critical to assist in the management of SLE patients. Therefore, it is necessary to measure disease activity changes by looking at all possible manifestations (Feld and Isenberg, 2014). Several scoring systems can assess SLE activity, one of which is the Systemic Lupus Erythematosus Disease Activity Index (SLEDAI). SLEDAI is considered the easiest scoring system to use in its application because it has the fewest variables and can be completed in a short time. The SLEDAI assessment has the minimum number of 0 and the maximum of 105 with 24 
variables (Mosca, et al, 2007; Mikdashi and Nived, 2015).

Complement mediates tissue damage and influences the patient's prognosis. Complement levels will decrease because complement is involved in antibody defense in the tissues associated with increased disease activity. The complement level is normal; SLE tends to be calm. The complement level will decrease due to flares (Hospital for Special Surgery, 2015). C3 is normal when the level is 50 $\mathrm{mg} / \mathrm{dL}-120 \mathrm{mg} / \mathrm{dL}$, and $\mathrm{C} 4$ is normal when the serum level is $20 \mathrm{mg} / \mathrm{dL}-50 \mathrm{mg} / \mathrm{dL}$.

In a study conducted at Chang Gung Hospital, Taiwan, "Serum complement factor I is associated with disease activity of systemic lupus erythematosus" showed a significant negative correlation between complement $\mathrm{C} 3$ and $\mathrm{C} 4$ with disease activity $(\mathrm{r}=-0.552$ and $\mathrm{r}=-0.276)$ (Tseng et al., 2018). Based on this study, this study was conducted to analyze the correlation between serum complement $\mathrm{C} 3$ and C4 levels with disease activity in SLE patients in Dr. Soetomo Hospital, Surabaya. Also, Dr. Soetomo Hospital, Surabaya is a hospital type A owned by the government of East Java Province, which is the final referral hospital for eastern Indonesia so that its patients do not only come from Surabaya.

\section{METHODS}

This type of study is retrospective analytic observational with a cross-sectional study design. The independent variable was the complement level of $\mathrm{C} 3$ and $\mathrm{C} 4$, and the dependent variable was the activity of SLE disease. This study has received ethical approval from the ethics committee (No. 1411/KEPK/VIII/2019). Sampling was done by consecutive sampling.

The inclusion criteria for this study ware: 1) Patients diagnosed with SLE based on the criteria for Systemic Lupus International Collaborating Clinics (SLICC) in 2012,2 ) SLE patients were treated in the inpatient room and poly rheumatology between January - December 2018, 3) SLE patients had data on complement levels of C3 and C4 in their medical records, and 4) SLE patients were 15-50 years old. The exclusion criteria were patients with congenital hypo-complement urticaria disease which can affect the low levels of complement $\mathrm{C} 3$ and $\mathrm{C} 4$. Based on these inclusion and exclusion criteria, 150 patients were obtained (Figure 1). Samples information about gender, age, work activity, laboratory tests, risk factors, and comorbidities were obtained from medical records.

Before analyzing the results, the sample was identified based on the SLEDAI scoring system. SLEDAI was used to assess SLE disease activity and the type used was SELENA-SELEDAI. SLE patients' symptoms and clinical manifestations were taken not far from the day when the complement levels of $\mathrm{C} 3$ and $\mathrm{C} 4$ were examined so that the results of the study were more accurate. If there is inappropriate data, it will be excluded from the study. Disease activity was divided into 5 groups based on the assessment resultst: remission score 0 , mild flare score 1-5, moderate flare score 6-10, severe flare score 11-20, and very severe flare score $>20$.

The collected data were analyzed using the Pearson test. A p-value of less than 0.05 was considered statistically significant. The value of $r$ : $0-0.25$ is considered to have a weak correlation, $0.26-0.50$ is considered to have a moderate correlation, 0.51-0.75 is considered to have a strong correlation, and 0.76-1 is considered to have a very strong correlation. SPSS
(Statistical Package for Social Sciences) software for Windows version 16 was used for statistical analysis.

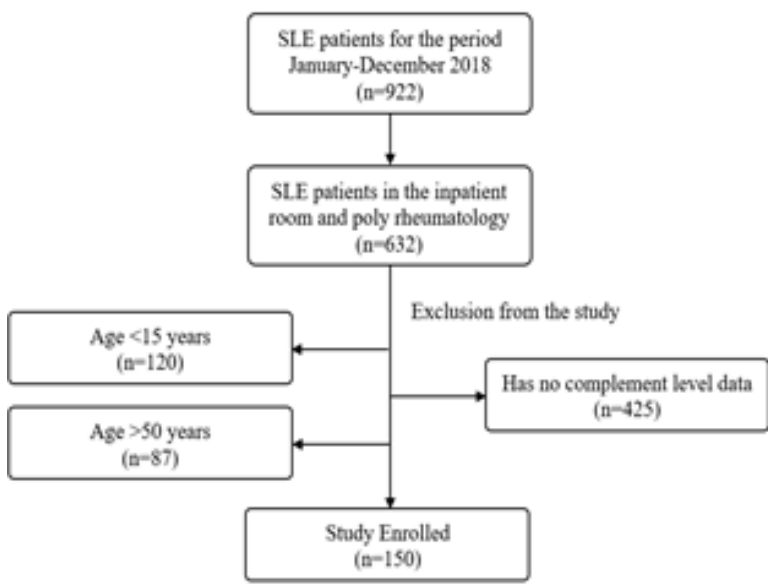

Figure 1. Patients enrollment flow chat

\section{RESULTS}

\section{Characteristics in patients with SLE}

One hundred and fifty SLE patients ( 135 females and 15 males, Figure 1) with a mean age of $29.01 \pm 9.8$ years (age range 15 50 years) were enrolled during this study period. Most of the patients did not work. The results of the examination of most complement C3 and C4 levels in SLE patients were low levels and the patient's activity was in a severe flare phase as shown in Table 1 .

Table 1. The Characteristics in patients with SLE

\begin{tabular}{|c|c|c|c|}
\hline Characteristics & $\mathrm{N}$ & $\%$ & $\begin{array}{l}\text { Mean } \pm \mathrm{SD} \\
(\min -\mathrm{max})\end{array}$ \\
\hline \multicolumn{4}{|l|}{ Gender } \\
\hline Men & 15 & 10,0 & \\
\hline Woman * & 135 & 90,0 & \\
\hline \multicolumn{4}{|l|}{ Age } \\
\hline $15-19$ & 31 & 20,7 & \multirow{4}{*}{$\begin{array}{c}29,01 \pm \\
9,8(15-50)\end{array}$} \\
\hline $20-32 *$ & 65 & 43,3 & \\
\hline $33-45$ & 42 & 28,0 & \\
\hline $46-50$ & 12 & 8,0 & \\
\hline \multicolumn{4}{|l|}{ Work activity } \\
\hline Yes & 59 & 39,3 & \\
\hline Not* & 91 & 60,7 & \\
\hline \multicolumn{4}{|c|}{$\begin{array}{l}\text { Levels of complement } \\
\text { C3 }\end{array}$} \\
\hline Low * & 72 & 48,0 & \multirow{3}{*}{$\begin{array}{c}63,37 \pm \\
42,8(2-184)\end{array}$} \\
\hline Normal & 61 & 40,7 & \\
\hline High & 17 & 11,3 & \\
\hline \multicolumn{4}{|c|}{ Levels of complement $\mathrm{C} 4$} \\
\hline Low * & 76 & 50,7 & \multirow{3}{*}{$\begin{array}{c}25,09 \pm \\
20,8(3-91)\end{array}$} \\
\hline Normal & 57 & 38,0 & \\
\hline High & 17 & 11,3 & \\
\hline Disease Activity & & & \\
\hline
\end{tabular}




\begin{tabular}{|c|c|c|c|}
\hline Remission & 6 & 4,0 & \multirow{5}{*}{$\begin{array}{c}14,17 \pm 7,7 \\
(0-37)\end{array}$} \\
\hline Mild flare & 15 & 10,0 & \\
\hline Medium flare & 28 & 18,7 & \\
\hline Several flare * & 67 & 44,7 & \\
\hline Very severe flare & 34 & 22,7 & \\
\hline
\end{tabular}

* The largest number

Frequency distribution of symptoms and manifestations

Most patients had symptoms and manifestations of impaired renal function. A minority had seizures, psychosis, central nervous disorders, headaches, and vasculitis.

Table 2. Distribution of Symptoms and Manifestations

\begin{tabular}{lc}
\hline Symptoms and manifestations of SLE & $\mathrm{N}(\%)$ \\
\hline Seizure & $5(3,3)$ \\
\hline Psychosis & $4(2,7)$ \\
\hline Organic brain syndrome & $23(15,3)$ \\
\hline Visual Disturbance & $9(6,0)$ \\
\hline Cranial Nerve Disorder & $4(2,7)$ \\
\hline Lupus headache & $5(3,3)$ \\
\hline CVA & $30(20,0)$ \\
\hline Vasculitis & $3(2,0)$ \\
\hline Arthritis & $9(6,0)$ \\
\hline Miositis & $7(4,7)$ \\
\hline Urinary cast & $3(2,0)$ \\
\hline Hematuria $*$ & $62(41,3)$ \\
\hline Proteinuria $*$ & $79(52,7)$ \\
\hline Pyuria & $44(29,3)$ \\
\hline New Rash & $22(14,7)$ \\
\hline Alopecia & $15(10,0)$ \\
\hline Mucosal Ulcers & $21(14,0)$ \\
\hline Pleurisy & $29(19,3)$ \\
\hline Pericarditis & $8(5,3)$ \\
\hline Increased DNA binding & $16(10,7)$ \\
\hline Fever & $14(9,3)$ \\
\hline Thrombocytopenia & $41(27,3)$ \\
\hline Leukopenia & $13(8,7)$ \\
\hline The largest number & \\
\hline
\end{tabular}

Correlation between complement levels with disease activity

Table 3. Correlation between complement C3 and disease activity

\begin{tabular}{lllll}
\hline \multirow{2}{*}{ Disease Activity } & \multicolumn{3}{c}{ Levels of complement } & \\
\cline { 2 - 4 } & Low & Normal & High & Tearson \\
\cline { 2 - 4 } Remission & 0 & 6 & 0 & \\
\hline Mild flare & 3 & 11 & 1 & \\
\cline { 1 - 4 } $\mathrm{p}=0.026$ & $\mathrm{r}=-0.182$ \\
Medium flare & 9 & 14 & 5 & \\
Several flare & 36 & 22 & 9 & \\
Very severe flare & 24 & 8 & 2 & \\
\hline
\end{tabular}

Table 3 shows that patients in the remission phase are only patients with normal complement $\mathrm{C} 3$ or $\mathrm{C} 4$ levels. Meanwhile, the flare phase varied and was dominated by the several flare phase with low complement $\mathrm{C} 3$ and $\mathrm{C} 4$ levels. Mild flares were most common in patients with normal complement levels, moderate flares were most in patients with low and normal complement levels, and very severe flares were most in patients with low complement levels. $\mathrm{C} 3$ and $\mathrm{C} 4$ had a negative (opposite direction) correlation with disease activity and the level of correlation shown a weak correlation.

Table 4. Correlation between complement $\mathrm{C} 4$ and disease activity

\begin{tabular}{|c|c|c|c|c|}
\hline \multirow{2}{*}{$\begin{array}{l}\text { Disease } \\
\text { Activity }\end{array}$} & \multicolumn{3}{|c|}{ Levels of complement C4 } & \multirow{2}{*}{$\begin{array}{l}\text { Pearson } \\
\text { Test }\end{array}$} \\
\hline & Low & Normal & High & \\
\hline Remission & 0 & 6 & 0 & \multirow{5}{*}{$\begin{array}{l}\mathrm{p}=0.026 \\
\mathrm{r}=-0.182\end{array}$} \\
\hline Mild flare & 5 & 7 & 3 & \\
\hline Medium flare & 10 & 10 & 8 & \\
\hline Several flare & 40 & 23 & 4 & \\
\hline $\begin{array}{l}\text { Very severe } \\
\text { flare }\end{array}$ & 21 & 11 & 2 & \\
\hline
\end{tabular}

\section{DISCUSSION}

SLE disease is more commonly known as a disease of adult women of childbearing age; only $10 \%-20 \%$ of cases occur in children (Tseng et al., 2018). Thus, the study was carried out on patients aged 15 to 50 years. Based on the results of the analysis (Table 1), it was found that most patients were female $(90.0 \%)$. The most patient age range was $20-32$ years $(43.3 \%)$ with the mean age of the subjects was $29.01 \pm 9.8$ years.

In a study conducted at the First Hospital of Jilin University (Changchun, China), 90 patients involved were 87 female patients and 3 male patients with a mean age of 38 \pm 13.9 years (Yuan et al., 2019). Weckerle and Niewold in 2011 stated that the ratio of the incidence of women and men is 9:1. The peak incidence of SLE in their study occurred in women of reproductive age, while men were older (Weckerle and Niewold, 2011). In another study at the Assiut University Hospital, Egypt, 51 female patients $(86.4 \%)$ were obtained from a total of 59 samples with a mean age of $31.3 \pm 10.5$ years (Mohamed et al., 2019). Overall studies have been conducted to show the same results. SLE is more common in women so that it occurs in patients of reproductive age. This happened because one of the risk factors for SLE played a role in the disease's course is hormones. The high risk for women is related to levels of the hormone estrogen so that men have a lower risk (Kementrian Kesehatan, 2017).

Based on the work activity, 59 SLE patients who worked, and 91 patients did not. Patients did not work because some of them stop working after being diagnosed with lupus. A study in London obtained that SLE patients had poor physical abilities, poor health conditions, low social functioning, and continuous pain impacted by the patient's activity (Sutcliffe et al., 1999). Another study in Bangkok, Thailand also concluded that SLE is a disease that can experience repeated flares that can limit the patient's physical activity. Furthermore, SLE disease activity can affect the activities carried out by patients (Chaiamnuay et al., 2010). Assessment of disease activity is critical to determine the appropriate management and prognosis of SLE patients. Disease activity in this study was calculated using the SLEDAI scoring system seen from SLE patients' medical 
records. SLE disease activity represents the intensity of inflammation, and various symptoms also manifestations (Feld and Isenberg, 2014). Inflammation in SLE occurs due to the accumulation of antigen-antibody complexes in the tissue through a type III hypersensitivity reaction (Marc and Olson, 2009). Thus, management that is good for SLE patients is life-long, treatment depending on the type and severity of the disease (Maidhof and Hilas, 2012). In short, if the patient is given appropriate management, disease activity may be avoided so that the mortality and morbidity of SLE patients can be suppressed (The Lupus Foundation of America, 2013). Studies on the relationship between complement levels and disease activity have varied results from one another. The difference in study results can because not all patients diagnosed with SLE have complement levels that match disease activity. Thus, this study aimed to analyze the relationship between serum complement C3 and C4 levels and SLE patients' disease activity.

Based on the results (Table 1), most of the patients were in the severe flare phase as many as 67 patients $(44.7 \%)$. An increase in disease activity might be caused by a combination of risk factors. If the combination of these factors continues, the manifestations in the patient will get worse. Patients with a remission phase should avoid risk factors that can aggravate the disease (Fanouriakis and Bertsias, 2019). Increased activity can also occur due to impaired immunity in patients due to not routine controls of the hospital. Some SLE patients in the study did not do routine controls. This affects the patient's condition when the patient who comes to control obtains new manifestations, and manifestations become more severe.

In general, SLE patients will represent symptoms and manifestations depending on the organs involved. Base on this study (Table 2), most patients represented symptoms and manifestations of impaired renal function. This study is in line with Bertsias et al. (2015) stating that kidney involvement often occurs in $40-70 \%$ of SLE patients and is a significant cause of morbidity and hospitalization (Bertsias et al, 2015). A study which aims to describe the clinical and immunological characteristics of SLE in Arab, found the most common symptoms and clinical manifestations are arthritis or arthralgia followed by anemia, fatigue, malar rash, and kidney manifestations (Adwan, 2019). Thus, further examination is needed for SLE patients using urinalysis and kidney biopsy. Urinalysis is an essential and effective method of detecting and monitoring disease activity. With the urinalysis method, you can see the levels of proteinuria, pyuria, and hematuria. While a kidney biopsy rarely helps diagnose lupus, it is the best way to document the pathology of the kidney (Bertsias et al, 2015).

In this study, the data on serum complement $\mathrm{C} 3$ and $\mathrm{C} 4$ levels in SLE patients were divided into three levels: low, normal, and high complement levels. This study shows that the flare phase can occur in patients with low or normal complement levels, and patients with a remission phase occur in patients with normal complement levels. It was found that the most complement levels of C3 and C4 in SLE patients were low complement levels (48.0\% and 50.7\%). $\mathrm{C} 3$ and $\mathrm{C} 4$ were consistently low in patients who were evenly distributed between infection and disease activity (Weckerle and Niewold, 2011). Thus, the increasing value of disease activity causes complement levels to decrease to help the immune process/body defense (Kim et al., 2019).

The Pearson correlation test (Tables 3 and 4) show a negative correlation between serum complement $\mathrm{C} 3$ and $\mathrm{C} 4$ levels with disease activity, with a weak correlation level.
This study is in line with a study conducted at the New Delhi Army Hospital, (51 SLE patients involved) more patients with low complement levels $(92.3 \%$ low C3 complement, and $84.9 \%$ low C4 complement) in patients with cases of renal flare. Meanwhile, in cases of non-renal flare, the low complement C3 levels were less. The study also stated a negative correlation between the complement levels of $\mathrm{C} 3$ and $\mathrm{C} 4$ and disease activity ( $\mathrm{r}-0.445$ and $\mathrm{r}-0.355)$ (Narayanan et al., 2010). Another study in Chang Gung University also proved a negative relationship between serum complement $\mathrm{C} 3$ and $\mathrm{C} 4$ levels and the disease activity of forty lupus patients involved in the study $(\mathrm{r}=-0.552$ and $\mathrm{r}=-0.276)$ (Tseng et al., 2018). Therefore, complement levels $\mathrm{C} 3$ and $\mathrm{C} 4$ are used as one of the criteria for patient diagnosis based on the SLICC 2012 and are useful for predicting SLE disease activity.

The lower the complement C3 and C4 levels that occur, the more disease activity that occurs. This can be seen from the results of examining the complement levels through the radial immunodiffusion method, which decreased below normal in patients who had increasingly severe disease activity levels. Increased disease activity indicates that SLE has clinical manifestations, eitherhaving ahistoryofpreviousmanifestations or increasing other manifestations. However, it does not rule out that SLE patients with strenuous activity have normal or above normal complement levels. The cause of inflammation in the SLE is not only due to complement but also due to other causes.

At Washington University School of Medicine, 159 patients were diagnosed with lupus and showed a correlation between $\mathrm{C} 3$ levels and levels of disease activity and clinical changes in disease activity. C3 levels in patients with active disease are lower than those in inactive disease (Kim et al., 2019). Meanwhile, a study in London did not show a correlation between complement $\mathrm{C} 4$ and disease activity. The low levels of complement $\mathrm{C} 4$ in the SLE patients studied could stem from the ingestion and production of a genetically defective immune system (Senaldi et al., 1988). Decreased levels of complement $\mathrm{C} 4$ can be associated with congenital diseases. In individuals with the HLA-B8 (DR3) genetic makeup, $\mathrm{C} 4$ levels are low throughout life. If lupus occurs, the $\mathrm{C} 4$ level tends to drop more than the baseline level and will continue to show low or normal-low levels regardless of disease activity. Therefore, it is necessary to carry out genetic testing on patients (Sandhu and Quan, 2017).

\section{CONCLUSION}

There is a correlation between serum complement $\mathrm{C} 3$ and C4 levels with SLE patients' disease activity in Dr. Soetomo Hospital Surabaya, which is significant, weak, and opposite. Thus, serum complement levels can describe the disease activity of SLE patients. Further studies are needed with a more sophisticated methodology and a larger sample or other variables that are thought to affect the severity of lupus.

\section{ACKNOWLEDGEMENT}

The author thanks the parties involved in completing this study: 1. Dr. Betty Agustina Tambunan, dr, Sp.PK (K) and Dr. Awalia, dr, Sp.PD-KR, FINASIM ware examiner who provided advice and shared useful knowledge in the preparation of this research.

2. Field of Research and Development in Dr. Soetomo Hospital Surabaya and his staff who helped and gave permission in this study.

3. Atika, S.Si., M.Kes was methodology and statistics supervisor. 


\section{CONFLICT OF INTEREST}

The authors declare there is no conflict of interest.

\section{REFERENCES}

Adwan, M. (2019) 'Clinical and Serologic Characteristics of Systemic Lupus Erythematosus in the Arab World: A Pooled Analysis of 3,273 Patients', Archives of Rheumatology, 33(4), pp. 455-463. doi: 10.5606/archrheumatol.2018.6832.

Bertsias, G., Cervera, R. and T Boumpas, D. (2015) 'Systemic Lupus Erythematosus: Pathogenesis and Clinical Features', EULAR Textbook on Rheumatic Diseases, (1909), pp. 476-505.

Chaiamnuay, S. et al. (2010) Health related quality of life and disease severity of SLE patients in Phramongkutklao Hospital, J Med Assoc Thai. Available at: https://pubmed. ncbi.nlm.nih.gov/21280525/ (Accessed: 30 July 2020).

Fanouriakis, A. and Bertsias, G. (2019) 'Changing paradigms in the treatment of systemic lupus erythematosus', Lupus Science and Medicine, 6(1), pp. 1-10. doi: 10.1136/lupus-2018-000310.

Feld, J. and Isenberg, D. (2014) 'Why and how should we measure disease activity and damage in lupus?', Presse Medicale, 43(6P2). doi: 10.1016/j.lpm.2014.03.002.

Gandino, I. J. et al. (2017) 'Complement levels and risk of organ involvement in patients with systemic lupus erythematosus', Lupus Science and Medicine, 4(1), pp. 1-5. doi: 10.1136/lupus-2017-000209.

Hikmah, Z. and Prihaningtyas, R. A. (2018) Bersahabat dengan lupus: kupas tuntas SLE pada anak. Jakarta: PT Gramedia.

Hospital for Special Surgery (2015) Understanding Lupus Lab Tests and Results for Lupus (SLE). Available at: https:// www.hss.edu/conditions_understanding-laboratory-tests-and-results-for-systemic-lupus-erythematosus. asp (Accessed: 24 May 2019).

Judha, M. and Setiawan, D. I. (2015) Apa dan Bagaimana Penyakit Lupus? (Sistemik Lupus Eritematosus). 1st edn. Gosyen Publishing.

Kementrian Kesehatan (2017) Infodatin situasi lupus di indonesia 2017. Pusat Data dan Informasi Kementrian Kesehatan RI.

Kim, A. H. J. et al. (2019) 'Association of Blood Concentrations of Complement Split Product iC3b and Serum C3 With Systemic Lupus Erythematosus Disease Activity', Arthritis and Rheumatology, 71(3), pp. 420-430. doi: 10.1002/art.40747.

Maidhof, W. and Hilas, O. (2012) 'Lupus: an overview of the disease and management options.', P \& T : a peer-reviewed journal for formulary management, 37(4), pp. 240-9. Available at: http://www.ncbi.nlm.nih.gov/ pubmed/22593636\%0Ahttp://www.pubmedcentral.nih. gov/articlerender.fcgi?artid=PMC3351863.

Marc, D. and Olson, K. (2009) 'Hypersensitivity Reactions and Methods of Detection', NeuroScience, Inc, pp. 1-4. Available at: http:// neurorelief.info/uploads/content_files/Hypersensitivity Reactions and Methods of Detection.pdf.

Mikdashi, J. and Nived, O. (2015) 'Measuring disease activity in adults with systemic lupus erythematosus: The chal- lenges of administrative burden and responsiveness to patient concerns in clinical research', Arthritis Research and Therapy, 17(1), pp. 1-10. doi: 10.1186/s13075-0150702-6.

Mohamed, A. A. A. et al. (2019) 'Cardiac Manifestations in Systemic Lupus Erythematosus: Clinical Correlates of Subclinical Echocardiographic Features', BioMed Research International, 2019, pp. 1-8. doi: 10.1155/2019/2437105.

Mosca, M., Merrill, J. T. and Bombardieri, S. (2007) Assessment of Disease Activity in Systemic Lupus Erythematosus. First Edit, Systemic Lupus Erythematosus: A Companion to Rheumatology. First Edit. Elsevier Inc. doi: 10.1016/B978-0-323-04434-9.50007-5.

Narayanan, K. et al. (2010) 'Correlation between systemic lupus erythematosus disease activity index, C3, C4 and anti-dsDNA antibodies', Medical Journal Armed Forces India, 66(2), pp. 102-107. doi: 10.1016/S03771237(10)80118-2.

Qu, C. et al. (2018) 'Value of combined detection of anti nuclear antibody, anti double stranded DNA antibody and C3, C4 complements in the clinical diagnosis of systemic lupus erythematosus', Experimental and Therapeutic Medicine, pp. 1390-1394. doi: 10.3892/etm.2018.7072.

Sandhu, V. and Quan, M. (2017) 'SLE and Serum Complement: Causative, Concomitant or Coincidental?', The open rheumatology journal, 11, pp. 113-122. doi: $10.2174 / 1874312901711010113$.

Senaldi, G. et al. (1988) 'Correlation of the activation of the fourth component of complement (C4) with disease activity in systemic lupus erythematosus', Annals of the Rheumatic Diseases, 47(11), pp. 913-917. doi: 10.1136/ ard.47.11.913.

Sutcliffe, N. et al. (1999) Associates of health status in patients with systemic lupus erythematosus - PubMed, J Rheumatol. Available at: https://pubmed.ncbi.nlm.nih. gov/10555890/ (Accessed: 29 July 2020).

The Lupus Foundation of America (2013) Understanding Lupus | Lupus Foundation of America. Available at: https:// www.lupus.org/understanding-lupus (Accessed: 20 May 2019).

Tseng, M.-H. et al. (2018) 'Serum complement factor I is associated with disease activity of systemic lupus erythematosus.', Oncotarget, 9(9), pp. 8502-8511. doi: 10.18632/ oncotarget. 23907.

Weckerle, C. E. and Niewold, T. B. (2011) 'The unexplained female predominance of systemic lupus erythematosus: Clues from genetic and cytokine studies', Clinical Reviews in Allergy and Immunology, 40(1), pp. 42-49. doi: 10.1007/s12016-009-8192-4.

Yuan, Y. et al. (2019) 'Association of toll-like receptor 9 expression with prognosis of systemic lupus erythematosus', Experimental and Therapeutic Medicine, pp. 32473254. doi: 10.3892/etm.2019.7290. 